\title{
Assessment of Nutrient and Heavy Metal Pollution in Channel Dredged Sediments in the middle and lower reaches of the Yangtze basin
}

\author{
Hongxia Xiong ${ }^{1 *}$, Shitao Peng ${ }^{1}$, Wei Huang ${ }^{1}$, Xinlei Liu ${ }^{2}$ and Xianbin Liu $^{2}$ \\ ${ }^{1}$ Tianjin Research Institute for Water Transport Engineering, Key Laboratory of Environmental Protection in Water transport \\ Engineering, Ministry of Transport, Tianjin 300456, China \\ ${ }^{2}$ Tianjin Key Lab of Marine Resource \& Chemistry, Tianjin Marine Environmental Protection and Restoration Technology Engineering \\ Center, Tianjin University of Science \& Technology, Tianjin 300457, China
}

\begin{abstract}
There was a large amount of dredged materials produced stably in the Yangtze waterway each year. How to dispose these dredged materials was a major technical problem in the field of port and waterway engineering. The dredged materials were valuable resource, and the utilization of dredged materials in landscape can be an important direction in the future. To analyze the feasibility of dredging for landscaping, the waterway dredged sediments from middle and lower reaches of the Yangtze River basin, such as Dongting Lake, Chenglingji section, Zhenjiang section, Nantong section and Taihu Lake were collected, and the nutrient characteristics, heavy metal content and pollution degree were analyzed. The results showed that the $\mathrm{pH}$, moisture content, petroleum hydrocarbons, organic matter and available $\mathrm{P}$ in Yangtze River waterway dredging sediments were 7.28 7.74, 3.75 28.27\%, 14.21 121.84 ppm, $1.88 \sim 5.29 \%$ and $16.96 \sim 65.38 \mathrm{ppm}$ respectively, which were moderate pollution and suitable for plants growth. The content of available $\mathrm{N}$ and available K content were 67.12 87.97 ppm and 2.78 20.11 ppm, which were too low to meet the needs of plant growth. Extra sources of nitrogen and potassium should be added into the sediments when reused. Dredged sediments were contaminated by heavy metals $\mathrm{Cu}, \mathrm{Pb}$ and $\mathrm{Zn}$, the evaluation results showed that their enrichment effect was not obvious, which won't affect the sediment utilization. Dredged sediments were widely contaminated by $\mathrm{Cd}(0.05 \sim 2.68 \mathrm{mg} / \mathrm{kg})$, and there was a certain enrichment effect, so some $\mathrm{Cd}$ hyperaccumulators should be planted to remediate $\mathrm{Cd}$ in dredged sediments.
\end{abstract}

\section{Introduction}

Dredging was necessary to create and maintain navigation channels for harbors and waterways. Billions of cubic yards of sediments were dredged each year. At a rough estimate, inland port and waterway engineering in China could produce 70 90 million cubic metres of dredged sediments each year[1].

Due to the constant input of the land-sourced pollutants and discharge of pollutants from waterway transportation itself to the river, dredged sediments from inland river were polluted by heavy metals ( $\mathrm{Yi}$ Y et al, 2011), nutrients (like nitrogen and phosphorus) and refractory organic matter [2]. Heavy metals in dredged sediments were often considered as conservative pollutants $[3,4]$, which could cause potential threat to ecosystems $[5,6]$.

Traditionally, dredged sediments were hydraulically raised and placed in confined disposal facilities [7]. Dredged sediments were rich in nutritive organic matters and could be used for surface soil enhancement rather than discarded as spoil material[8]. The Toledo-Lucas
County Port Authority (TLCPA) was currently leading an effort to plan for the full-scale implementation of beneficial use of dredged materials for agricultural and blended soil product purposes.

Yangtze River as the first river running through east and west China, which connecting the southwest, central, east three major economic zones to be a transportation artery. Yangtze River flowed across downtown with dense population and heavy industrialization and was affected by seriously industrial and domestic pollution, which had resulted in poor water quality in the estuary [9].

This study took the waterway dredged sediments from middle and lower reaches of the Yangtze River basin, such as Dongting Lake, Chenglingji section, Zhenjiang section, Nantong section and Taihu Lake as the research objects, and referred to the classification standard of soil nutrient elements as well as sediment background value of Yangtze River stream, to analyze and evaluate the nutrient and heavy metal pollution characteristics of the Yangtze River waterway dredging sediments, which would provide a scientific basis for recycling utilization of waterway dredged sediments.

\footnotetext{
*Corresponding author's e-mail: 529202551@qq.com
} 


\section{Materials and methods}

\subsection{Sample collection}

To investigate and verify the nutrient characteristics, heavy metal content and pollution degree in the dredged sediments of Yangtze River basin, Dongting Lake, Chenglingji section, Zhenjiang section, Nantong section and Taihu Lake were selected as the show study areas, which were shown in Figure 1.

The sediment samples were collected in November
2013 (rain season) and August 2014 (dry season). $1 \mathrm{~kg}$ sediment was sampled in each point. Sampled sediments were stored in a clean PE sealing bag, and then putted in a foam box with ice packs at the bottom. The foam box full of sediments were carried back to the laboratory within $24 \mathrm{~h}$ and then stored in refrigerator or determined immediately. Sediment samples were pretreated as follows: air-dried, removed the stones, animal and plant residues and other foreign matters in it, grinded, sifted through a 100 mesh sieve, and then placed in a dry condition.
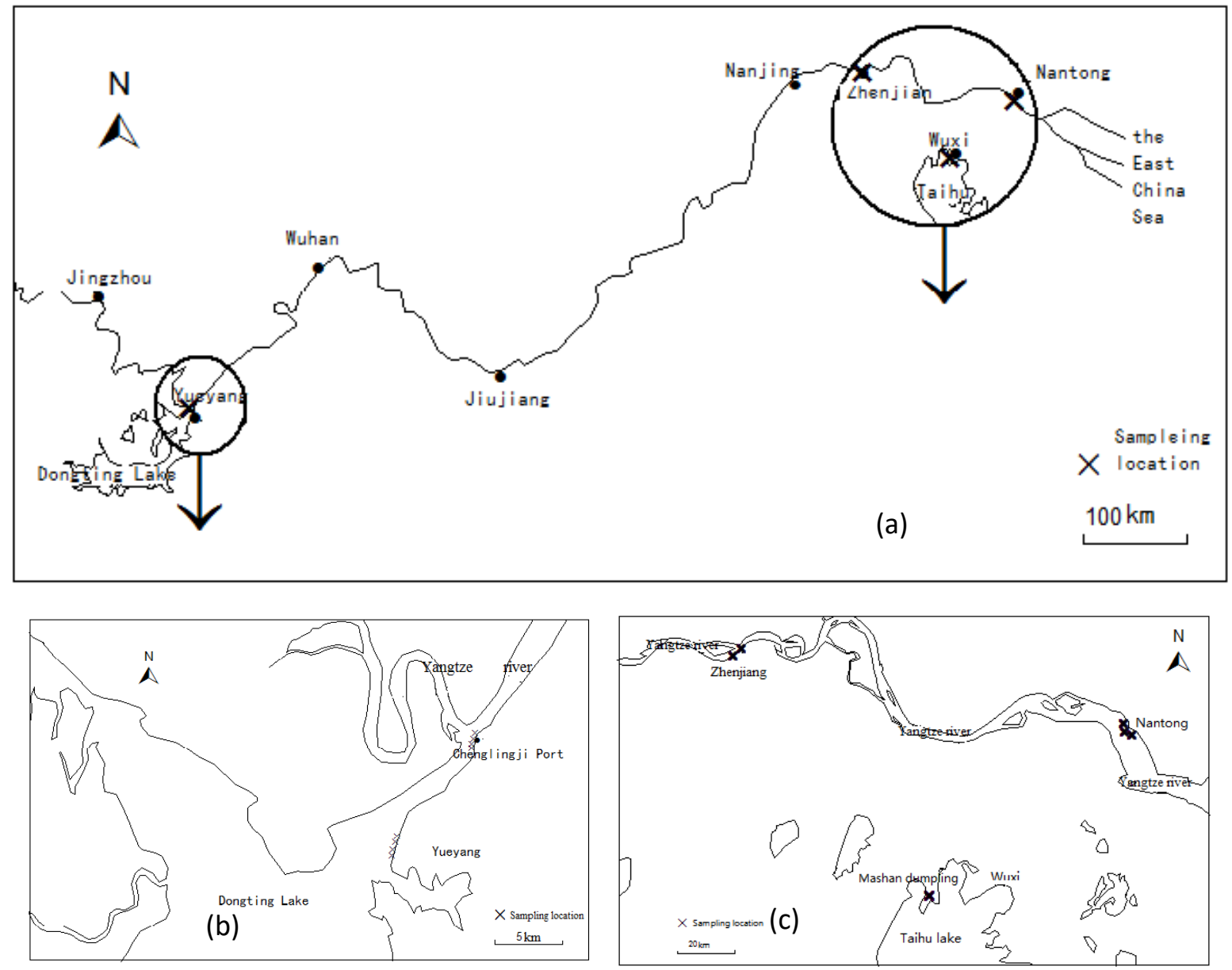

Figure 1. Sampling locations of the dredged sediments in the channel of Yangtze River (a); the general location of sampling sites of each area (b) (c).

\subsection{Testing items and methods}

The physical and chemical properties of dredged sediments were analyzed, including plant nutrients, pollution relevant as well as other properties. Specific analysis indicators, methods and significance were shown in Table 1.

Table 1. Physico-chemical properties analysis parameters and methods of dredged materials.

\begin{tabular}{|c|c|c|}
\hline Analysis Index & Analysis Methods & Analysis Meaning [10] \\
\hline $\mathrm{pH}$ & Potentiometry & $\begin{array}{l}\text { Closely related to the biological } \\
\text { effectiveness of heavy metals and nutrients }\end{array}$ \\
\hline $\begin{array}{l}\text { Petroleum } \\
\text { hydrocarbons }\end{array}$ & $\begin{array}{l}\text { N-Hexane extraction - spectrophotometric } \\
\text { colorimetry }\end{array}$ & One of the main pollutants in the channel \\
\hline Organic matter & $\begin{array}{l}\text { Potassium dichromate oxidation - ferrous } \\
\text { sulphatetitrimetry }\end{array}$ & $\begin{array}{l}\text { The main carrier of plant nutrients, and an } \\
\text { important index of soil fertility }\end{array}$ \\
\hline Available N & Alkaline hydrolysis diffusion & $\begin{array}{l}\text { The nitrogen that can be directly used by } \\
\text { plants }\end{array}$ \\
\hline Available P & $\mathrm{NaHCO}_{3}$ leaching-molybdenum antimony & An index representing the ability of soil to \\
\hline
\end{tabular}




\begin{tabular}{lll}
\hline \multirow{2}{*}{ Available $\mathrm{K}$} & $\begin{array}{l}\text { colorimetry } \\
\text { Ammonium acetate extraction - atomic } \\
\text { absorption spectrophotometry }\end{array}$ & $\begin{array}{l}\text { supply Available } \mathrm{P} \\
\text { An index representing the ability of soil to } \\
\text { supply Available } \mathrm{K}\end{array}$ \\
Heavy metals & $\begin{array}{l}\text { Digested by } \mathrm{HNO}_{3}+\mathrm{HClO}_{4}, \text { measured by } \\
\text { ICP-MS }\end{array}$ & \\
\hline
\end{tabular}

\subsection{Evaluation standards and methods}

matter, available nitrogen, phosphorus and available potassium were graded and evaluated referring to the classification standard of soil nutrients (see Table 2).

\subsubsection{Evaluation standard of dredged sediments for nutrient characteristics. Indicators such as organic}

Table 2. Soil nutrient classification standard in China.

\begin{tabular}{lllll}
\hline \multicolumn{1}{c}{ Levels } & \multicolumn{1}{c}{$\begin{array}{c}\text { Organic matter } \\
(\%)\end{array}$} & Available N (ppm) & Available P (ppm) & Available K $(\mathrm{ppm})$ \\
\hline 1 very rich & $>4$ & $>150$ & $>40$ & $>200$ \\
2 rich & $3 \sim 4$ & $120 \sim 150$ & $20 \sim 40$ & $150 \sim 200$ \\
3 moderate & $2 \sim 3$ & $90 \sim 120$ & $10 \sim 20$ & $100 \sim 150$ \\
4 lack & $1 \sim 2$ & $60 \sim 90$ & $5 \sim 10$ & $50 \sim 100$ \\
5 very lack & $0.6 \sim 1$ & $30 \sim 60$ & $3 \sim 5$ & $30 \sim 50$ \\
6 stunning lack & $<0.6$ & $<30$ & $<3$ & $<30$ \\
\hline
\end{tabular}

\subsubsection{Analysis and evaluation of dredged sediments} for heavy metal pollution. The heavy metals $\mathrm{Pb}, \mathrm{Cd}, \mathrm{Cu}$,

and $\mathrm{Zn}$ were selected to assess the sediment quality of the eight situations. The reference values of heavy metals ( $Z$ et al, 1990) were shown in Table 3.

Table 3. Reference values of heavy metals.

\begin{tabular}{lllll}
\hline Heavy metals & $\mathrm{Cu}$ & $\mathrm{Pb}$ & $\mathrm{Zn}$ & $\mathrm{Cd}$ \\
\hline The first grade standard values of soil environmental & 35.0 & 35.0 & 100 & 0.20 \\
China soil environmental background values & 22.6 & 26.0 & 74.2 & 0.097 \\
Yangtze River stream sediment background value & 21.5 & 21.4 & 73.6 & 0.15 \\
\hline
\end{tabular}

Geoaccumulation index and single-factor pollution index were the two methods that mostly used as quantitative determination of the potential hazardous trace elements pollution in aquatic sediment.

The single factor index method could be expressed as formula (1):

$$
P_{i}=\frac{C_{i}}{S_{i}}
$$
$S_{i}(\mathrm{mg} / \mathrm{kg})$ was the environmental background value at Nanjing City region.

According to the relation between the evaluation indexes and the contamination degree, sediment pollution was divided into 4 grades (Table 4 ).

where $P_{i}$ was the pollution index of heavy metal $i ; C_{i}$

Table 4. Relation between the evaluation indexes and the contamination degree.

\begin{tabular}{lllll}
\hline $\begin{array}{l}\text { Evaluation } \\
\text { Indexes }\end{array}$ & $<1$ & $1 \sim 3$ & $3 \sim 6$ & $\geq 6$ \\
\hline $\begin{array}{l}\text { Contamination } \\
\text { Degree }\end{array}$ & $\begin{array}{l}\text { Slight } \\
\text { Contaminated }\end{array}$ & $\begin{array}{l}\text { Moderate } \\
\text { Contaminated }\end{array}$ & $\begin{array}{l}\text { Heavy } \\
\text { Contaminated }\end{array}$ & $\begin{array}{l}\text { Extremely } \\
\text { Contaminated }\end{array}$ \\
\hline
\end{tabular}

Geoaccumulation index (IG) method proposed by Müller was a quantitative research method on heavy metal pollution levels in sediment (especially sediment of aquatic environment) that reflects pollution level by evaluating heavy metal content in sediment. It can reveal the enrichment degree of heavy metals in sediment [11], and considered the influence of man-made pollution factors and natural diagenesis on background value, which has been widely adopted [12]. Calculation formula of Igeo was showed as formula (2).

$$
I_{g e o}=\log _{2}\left[C_{n} /\left(k B_{n}\right)\right]
$$

In the above formula,

$C_{n}$ _ measured content of heavy metal $\mathrm{n}$ in sediment $(\mathrm{mg} / \mathrm{kg})$.

$B_{n}$ - geochemical background value of heavy metal $\mathrm{n}$ of sediment. In this formula were the heavy metals element background values of sediment from Yangtze River stream adopted ( $\mathrm{mg} / \mathrm{kg}$ ).

$\mathrm{k}$ - modified index being mainly used to correct the change of background value caused by the effects as weathering, and generally take 1.5 .

According to the $I_{\text {geo }}$ values, pollution degree could be divided into seven grades, as shown in Table 5 . 
Table 5. Contamination degree corresponding to index of Geoaccumulation.

\begin{tabular}{|c|c|c|c|c|c|c|c|}
\hline Igeo & $<0$ & $0 \sim 1$ & $1 \sim 2$ & $2 \sim 3$ & $3 \sim 4$ & $4 \sim 5$ & $>5$ \\
\hline Grades & 0 & 1 & 2 & 3 & 4 & 5 & 6 \\
\hline $\begin{array}{c}\text { Pollution } \\
\text { Levels }\end{array}$ & Clear & Clear-moderate & Moderate & Moderate-strong & Strong & Strong-extremely Strong & $\begin{array}{c}\text { Extremely } \\
\text { Strong }\end{array}$ \\
\hline
\end{tabular}

\section{Results and discussions}

\subsection{Physicochemical properties and nutrient characteristics of dredged sediments.}

The $\mathrm{pH}$ was an important factor for affecting, adjusting and controlling the matter migration of pedosphere. Physicochemical properties and nutrient characteristics of waterway dredged sediments from Yangtze River basin were shown in Table 6. The $\mathrm{pH}$ of the dredged sediments from the study areas was between 7.11 7.87, showing weak alkaline, suitable for the growth of most plants. The moisture content was abundant enough to meet the needs of the plant growth.

The quality standard value for petroleum hydrocarbons content of river and lake sediment was refered to the first grade standard values of soil environmental $(100 \mathrm{mg} / \mathrm{kg})$ in this study. As shown in Table 6 , the petroleum hydrocarbon content was between $4.63 \sim 121.84 \mathrm{mg} / \mathrm{kg}$. Petroleum hydrocarbon content of sediments from Dongting Lake and Chenglingji Sectionwss higher than other sample areas. Petroleum hydrocarbon content of sediments from Dongting Lake exceeded the first grade standard values of soil environmental, thus some measures should be taken to control the harmful effect when recycling utilization of dredged sediments. Nevertheless, the petroleum hydrocarbon content of sediment from other sample areas would not affect the utilization of dredged sediments.

The organic matter of dredged sediment was between $0.70 \sim 10.10 \%$. For organic matter, sediments from Dongting Lake and Chenglingji Section reached level 1(very rich), sediments from Taihu Lake reached level 2 (rich), sediments from Zhenjiang section reached level 3 (moderate), and sediments from Nantong section reached level 4 (lack). Consequently, dredged sedimenst from Dongting Lake, Chenglingji Section, Taihu Lake and Zhenjiang Section could supported landscape application, however, sediments from Nantong Section needed adding extra organic matter to improve the fertility.

The content of available nitrogen in dredged sediment was between $28.98 \sim 174.87 \mathrm{mg} / \mathrm{kg}$, and the sediments lacked the available nitrogen; nevertheless, few sampling points in Zhenjiang Section reached a high and above level.

Table 6. Physicochemical and nutrient properties of sediment samples from Yangtze River basin.

\begin{tabular}{llrrrr}
\hline & Dongting Lake & \multicolumn{1}{l}{$\begin{array}{l}\text { Chenglingji } \\
\text { Section }\end{array}$} & \multicolumn{1}{l}{$\begin{array}{l}\text { Zhenjiang } \\
\text { Section }\end{array}$} & \multicolumn{1}{c}{$\begin{array}{l}\text { Nantong } \\
\text { Section }\end{array}$} & \multicolumn{2}{c}{ Taihu Lake } \\
\hline $\mathrm{pH}$ & $7.61 \pm 0.06$ & $7.61 \pm 0.16$ & $7.63 \pm 0.02$ & $7.74 \pm 0.12$ & $7.28 \pm 0.27$ \\
Moisture content/\% & $23.87 \pm 1.14$ & $23.75 \pm 2.85$ & $28.27 \pm 1.22$ & $23.92 \pm 0.56$ & $25.80 \pm 3.44$ \\
Petroleum Hydrocarbons & $121.84 \pm 91.24$ & $57.74 \pm 35.68$ & $26.73 \pm 4.63$ & $34.66 \pm 5.80$ & $14.21 \pm 6.38$ \\
/ppm & $5.29 \pm 0.54$ & $5.15 \pm 1.27$ & $2.07 \pm 0.46$ & $1.88 \pm 0.03$ & $3.41 \pm 2.69$ \\
Organic matter /\% & $68.20 \pm 6.54$ & $78.88 \pm 4.66$ & $67.12 \pm 46.57$ & $73.83 \pm 0.26$ & $87.97 \pm 51.98$ \\
Available N /ppm & $65.38 \pm 26.50$ & $33.59 \pm 21.16$ & $22.88 \pm 14.99$ & $22.00 \pm 1.63$ & $16.96 \pm 7.07$ \\
Available P /ppm & $14.26 \pm 2.08$ & $8.31 \pm 3.60$ & $16.82 \pm 0.62$ & $2.78 \pm 0.40$ & $20.11 \pm 7.87$ \\
Available K/ppm & & & &
\end{tabular}

The content of available phosphorus in all the dredged sediments was between $7.32 \sim 81.82 \mathrm{mg} / \mathrm{kg}$. Average content of available phosphorus in dredged sediments from Dongting Lake reached level 1 (very rich), sediments from Chenglingji Section reached level 2 (rich), sediments from Zhenjiang Section and Nantong Section reached level 3 (moderate), sediments from Taihu Lake reached level 4 (lack), and needed adding additional source of phosphorus when landscape application. It was found that the content of available $\mathrm{P}$ in sediments from different sampling points at Dongting Lake and Chenglingji Section presented obviously fluctuations, and the content of available $\mathrm{P}$ in sediments from Taihu Lake and Nantong Section presented slightly fluctuations, however, the average content of all stations was at the same level.

The available potassium content in dredged sediments was between $2.37 \sim 33.74 \mathrm{mg} / \mathrm{kg}$, and almost all the sampling points were less than $30 \mathrm{mg} / \mathrm{kg}$, reaching 6 level (stunning lack). The available potassium was an essential element for plant growth, and supplement of available potassium fertilizer was required when sediment used as horticultural application.

\subsection{Pollution analysis and ecological risk assessment on heavy metal}

3.2.1 Analysis of heavy metal content and contamination level. Figure 2 presented the analysis results of heavy metals in dredged sediments from research area. Concentration of heavy metal $\mathrm{Cu}$ was between $1.95 \sim 62.76 \mathrm{mg} / \mathrm{kg}$, and the average concentration was $23.81 \mathrm{mg} / \mathrm{kg}$; the average content of $\mathrm{Cu}$ in dredged sediments from Dongting Lake and Chenglingji Section exceeded 
slightly the first grade standard values of soil environmental; and that from Zhenjiang Section was lower than the first grade standard values of soil environmental but higher than the Yangtze River stream sediment background value; and that from the other sampling areas was lower than the Yangtze River stream sediment background value. Variance coefficient of $\mathrm{Cu}$ in Chenglingji Section was highest, and Dongting Lake was next, and Nantong Section was the lowest.

Concentration of heavy metal $\mathrm{Pb}$ was between $9.56 \sim 41.64 \mathrm{mg} / \mathrm{kg}$, and the average concentration was $21.40 \mathrm{mg} / \mathrm{kg}$; $\mathrm{Pb}$ concentration of all sampling points were lower than the first grade standard values of soil environmental, but all points of Dongting Lake and Zhenjiang Section, and most points of Chenglingji Section were higher than the Yangtze River stream sediment background value; the rangeability of $\mathrm{Pb}$ concentration was generally low except of Chenglingji Section.
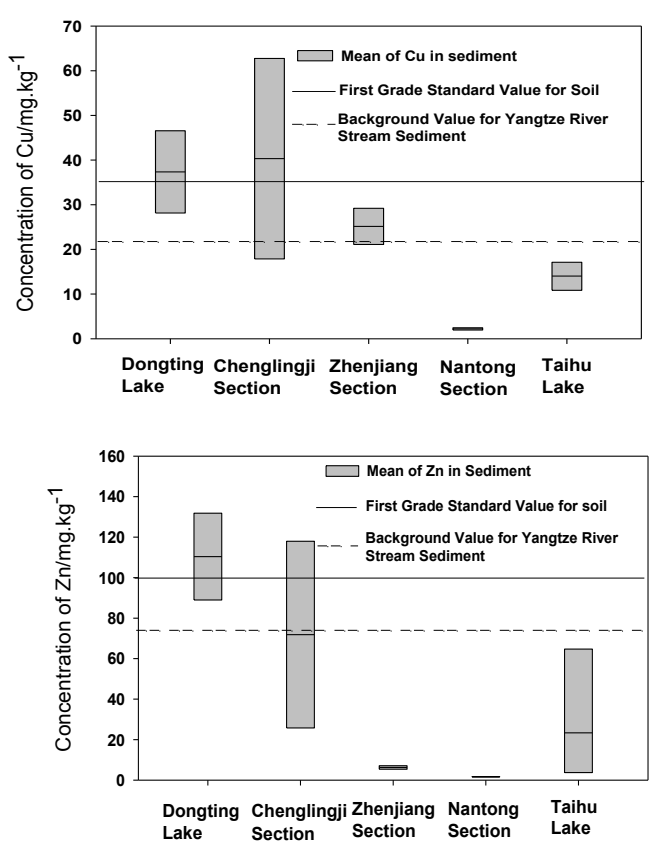

Figure 2. Concentrations of $\mathrm{Cu}, \mathrm{Pb}, \mathrm{Zn}$ and $\mathrm{Cd}$ in sediments from different areas.

In summary, Dongting Lake suffered the most serious heavy metal pollution. Chenglingji Section suffered some heavy metal pollution. The concentration of $\mathrm{Cd}$ in Taihu Lake exceeded certain limits, but the other heavy metals were low. With respect to Zhenjiang Section and Nantong Section, content of all heavy metals were at a low level. Concentration of heavy metals $\mathrm{Cu}, \mathrm{Pb}$ and $\mathrm{Zn}$ was relatively lower, however, content of $\mathrm{Cd}$ was generally high. Therefore, pollution of $\mathrm{Cd}$ was respected to be treated.

3.2.2 Assessment of heavy metal pollution. Evaluation result of single factor pollution index method was shown in Figure 3. With regard to heavy metal $\mathrm{Cu}$, pollution index of almost all sample points in Dongting
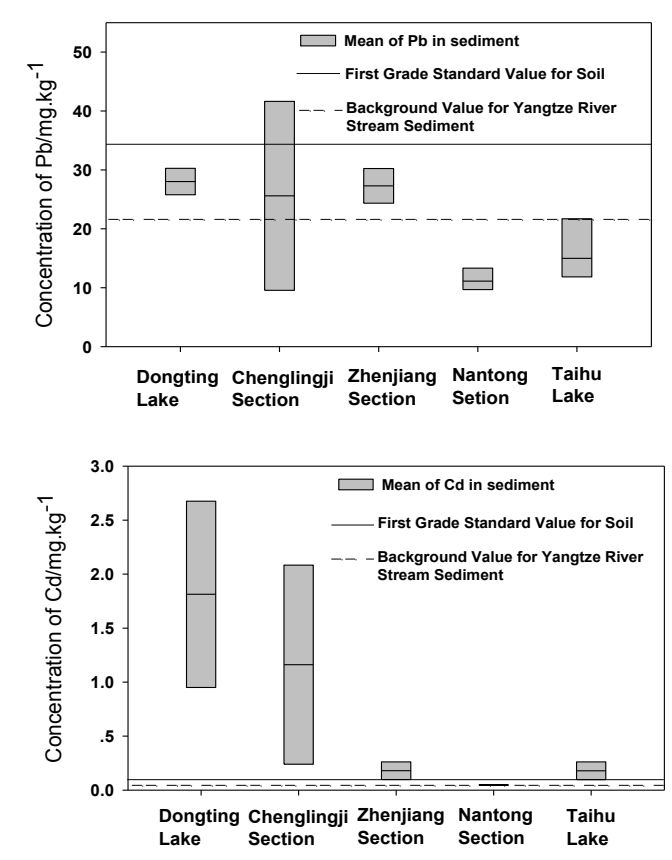

Concentration of heavy metal $\mathrm{Zn}$ was between $1.65 \sim 131.82 \mathrm{mg} / \mathrm{kg}$, and the average concentration was $42.70 \mathrm{mg} / \mathrm{kg}$; Of all the sampling areas, Zn concentration of most points was lower than the Yangtze River stream sediment background value, however, the content of some points of Dongting Lake, and few points of Chenglingji Section was higher than the first grade standard values of soil environmental. The variety range of $\mathrm{Zn}$ was generally high except of Zhenjiang Section and Nantong Section.

Cadmium content was between $0.05 \sim 2.68 \mathrm{mg} / \mathrm{kg}$, and the average concentration was $0.68 \mathrm{mg} / \mathrm{kg}$; Cd concentration of all research areas exceed the first grade standard values of soil environmental and the Yangtze River stream sediment background value. Furthermore, Cd concentration of Dongting Lake and Chenglingji Section even exceeded the second grade standard values of soil environmental $(0.6 \mathrm{mg} / \mathrm{kg})$. The highest concentration appeared in sampling area of Dongting Lake, which was 4.46 times higher than the second grade standard values.

Lake, and Zhenjiang Section was among 1 3, being in the medium pollution level; pollution indexes of all samples from Taihu Lake and Nantong Section were less than 1, being low pollution levels; pollution level of each study area arranging from high to low was respectively Chenglingji Section >Dongting Lake > Zhenjiang Setion $>$ Taihu Lake $>$ Nantong Lake. With respect with $\mathrm{Pb}$ : pollution index of all sample points in Dongting Lake, Zhenjiang Section and most of the sampling points in Chenglingji Section was in the range of $1 \sim 3$, being in the medium pollution level; pollution index of all samples from Nantong and most of the samples from Taihu Lake was below 1, being in low pollution level; pollution level of each study area arranging from high to low was respectively Dongting Lake $>$ Zhenjiang 
Setion $>$ Chenglingji Section $>$ Taihu Lake $>$ Nantong Lake. Regarding Zn: pollution index of all samples from Dongting Lake and some samples from Chenglingji Section was among 1 3, being in certain pollution levels; pollution index of all samples from the other study areas was all below 1, being in low pollution level; pollution level of each study area arranging from high to low was respectively Dongting Lake $>$ Chenglingji Section $>$ Taihu Lake $>$ Zhenjiang Setion $>$ Nantong Lake. As to Cd, pollution index of all samples from Dongting Lake and
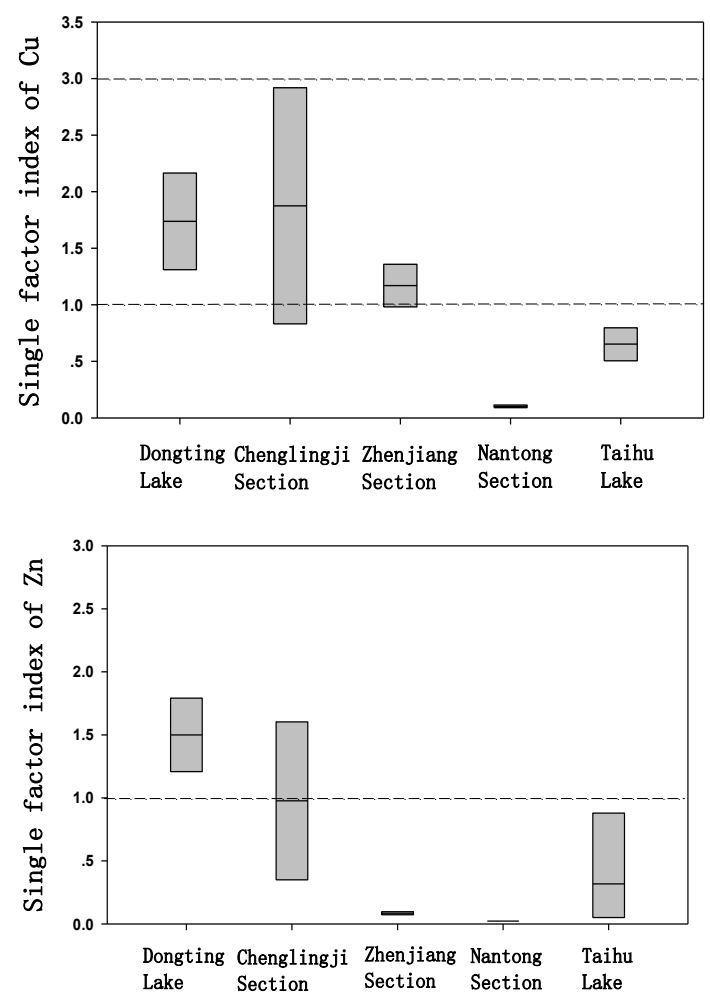

most samples from Chenglingji Section reached to 6, being in serious pollution level; pollution index of a few samples from Chenglingji Section and most samples from Chenglingji Section, Zhenjiang Section and Taihu Lake was in the range of $1 \sim 3$, being in medium pollution levels; pollution index of all samples from Nantong Section was all below 1, being slightly polluted; pollution level of each study area arranging from high to low was respectively Dongting Lake $>$ Chenglingji Section $>$ Zhenjiang Setion $>$ Taihu Lake $>$ Nantong Lake.
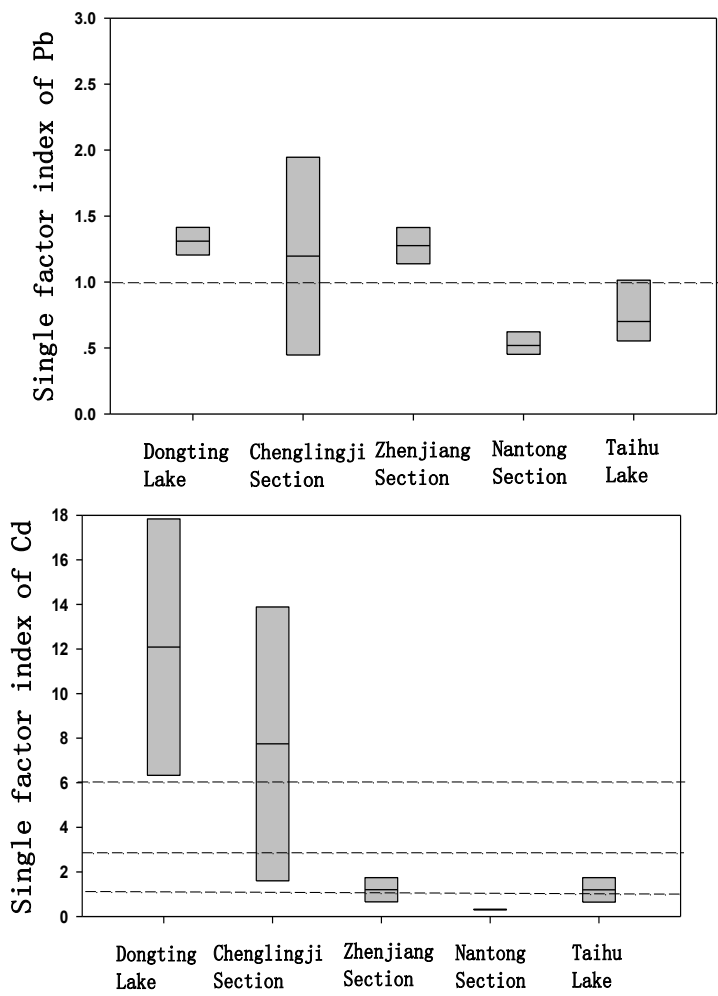

Figure 3. Single factor index $\left({ }^{C_{f}^{i}}\right)$ of $\mathrm{Cu}, \mathrm{Pb}, \mathrm{Zn}$ and $\mathrm{Cd}$ in sediments from different areas.

Note: dotted lines in figures represent classification boundaries of the single factor index, and the detailed classification standard are showed in Table 4.

The cumulative index evaluation results were shown in Table 7. In the study area, excepting of individual points that were subjected to moderate pollution by $\mathrm{Cu}$, $\mathrm{Pb}$ and $\mathrm{Zn}$, other sampling points were all clear with the three heavy metals. Apart from Nantong Section, there existed varying degrees of $\mathrm{Cd}$ contamination in other sampling regions, The sediments from Taihu Lake suffered a stronger degree of Cd pollution, and sediments from Chenglingji Section suffered a moderate - strong level of $\mathrm{Cd}$ pollution. Overall, enrichment effects of $\mathrm{Cu}$, $\mathrm{Pb}$ and $\mathrm{Zn}$ pollution in study areas of Yangtze River were generally lighter. However, enrichment effect of $\mathrm{Cd}$ pollution in midstream of Yangtze River like Taihu Lake and Chenglingji Section was rather serious, but that in middle and downstream such as Zhenjiang Section, Nantong Section and Taihu Lake was not critical.

Evaluation results showed that pollution of $\mathrm{Cu}, \mathrm{Pb}$ and $\mathrm{Zn}$ in Dongting Lake and Chenglingji Section was moderate level, but $\mathrm{Cd}$ was serious. $\mathrm{Cu}, \mathrm{Pb}$ and $\mathrm{Cd}$ of pollution in Zhenjiang Section was moderate level, but
$\mathrm{Zn}$ was not obvious. Pollution of all analyzed heavy metals in Taihu Lake and Nantong Section was rather lower. There existed a certain enrichment effects in midstream of Yangtze River like Dongting Lake and Chenglingji Section. Chenglingji was located in the mouth of East Dongting Lake, which was in middle and downstream of Yangtze River, belonging to Yueyang City. Chenglingji port was a national port, there were many industrial enterprises such as thermal power plant, paper mill, smelting factory, petrochemical corporation surround near the port. The sediment in the Chenglingji port was polluted by domestic sewage, industrial wastewater and ship oil-containing wastewater. So the $\mathrm{Cd}$ pollution in Chenglingji was the most serious. 
Table 7. Igeo and Pollution levels of $\mathrm{Cu}, \mathrm{Pb}, \mathrm{Zn}$ and $\mathrm{Cd}$ in sediments from different areas.

\begin{tabular}{cccccccc}
\hline & \multicolumn{6}{c}{ Research areas } \\
\cline { 3 - 8 } & & $\begin{array}{c}\text { Dongting } \\
\text { Lake }\end{array}$ & $\begin{array}{c}\text { Chenglingji } \\
\text { Section }\end{array}$ & $\begin{array}{c}\text { Zhenjiang } \\
\text { Section }\end{array}$ & $\begin{array}{c}\text { Nantong } \\
\text { Section }\end{array}$ & Taihu Lake & Mean \\
\hline \multirow{3}{*}{$\mathrm{Cu}$} & Max & $0.53 / 1$ & $0.96 / 1$ & $-0.14 / 0$ & $-3.72 / 0$ & $-0.91 / 0$ & $-0.66 / 0$ \\
& Min & $-0.20 / 0$ & $-0.85 / 0$ & $-0.61 / 0$ & $-4.05 / 0$ & $-1.57 / 0$ & $-1.46 / 0$ \\
& Mean & $0.21 / 1$ & $0.32 / 1$ & $-0.36 / 0$ & $-3.87 / 0$ & $-1.20 / 0$ & $-0.98 / 0$ \\
\hline \multirow{3}{*}{$\mathrm{Pb}$} & Max & $-0.09 / 0$ & $0.38 / 1$ & $-0.09 / 0$ & $-1.27 / 0$ & $-0.57 / 0$ & $-0.33 / 0$ \\
& Min & $-0.32 / 0$ & $-1.75 / 0$ & $-0.40 / 0$ & $-1.73 / 0$ & $-1.44 / 0$ & $-1.13 / 0$ \\
& Mean & $-0.20 / 0$ & $-0.33 / 0$ & $-0.23 / 0$ & $-1.53 / 0$ & $-1.10 / 0$ & $-0.68 / 0$ \\
\hline \multirow{2}{*}{$\mathrm{Zn}$} & Max & $0.26 / 1$ & $0.10 / 1$ & $-3.96 / 0$ & $-6.03 / 0$ & $-0.77 / 0$ & $-2.08 / 0$ \\
& Min & $-0.31 / 0$ & $-2.10 / 0$ & $-4.36 / 0$ & $-6.06 / 0$ & $-4.88 / 0$ & $-3.54 / 0$ \\
& Mean & $0.01 / 1$ & $-0.62 / 0$ & $-4.15 / 0$ & $-6.05 / 0$ & $-2.24 / 0$ & $-2.61 / 0$ \\
\hline \multirow{2}{*}{$\mathrm{Cd}$} & Max & $3.57 / 4$ & $3.21 / 4$ & $0.22 / 1$ & $-2.22 / 0$ & $0.21 / 1$ & $1.01 / 2$ \\
& Min & $2.08 / 3$ & $0.09 / 1$ & $-1.19 / 0$ & $-2.32 / 0$ & $-1.22 / 0$ & $-0.51 / 0$ \\
& Mean & $3.01 / 4$ & $2.37 / 3$ & $-0.32 / 0$ & $-2.26 / 0$ & $-0.33 / 0$ & $0.49 / 1$ \\
\hline
\end{tabular}

\section{Conclusion}

(1) The $\mathrm{pH}$ and moisture content of dredged sediments in the Yangtze River basin could meet the requirements of most of the plants growth. The content of petroleum hydrocarbon was generally out of limit for sediments from Dongting Lake. However, petroleum hydrocarbon of the other study areas would not influence the resource disposal of sediments.

(2) Organic matter content in Dongting Lake, Chenglingji Section, Taihu Lake and Zhenjiang Section all can satisfy the landscape use; however, organic matter in Nantong Section was slightly lower, and appropriate organic fertilizer should be added in the sediment to preserve soil fertility. Available $\mathrm{N}$ and $\mathrm{K}$ were widespread low in most of research areas, so additional source of $\mathrm{N}$ and $\mathrm{K}$ should be added to ensure the normal growth of plants for phytoremediation. Apart from individual sample points, available $\mathrm{P}$ could satisfy most plants growth.

(3) Although the dredged sediments from Yangtze River basin suffered varying degrees of $\mathrm{Cu}, \mathrm{Pb}$ and $\mathrm{Zn}$ pollution, it can meet the requirement of resource utilization because the enrichment effects was not obvious. However, Cd pollution was generally serious, and had a certain concentration effect. Therefore, plants for phytoremediation should be panted to reduce $\mathrm{Cd}$ content in dredged sediments.

\section{Acknowledgments}

This work was supported by the National Natureal Science Foundation of China (21677065), and the Fundamental Research Funds for the Central Public Welfare Reasearch Institutes (TKS190106).

\section{References}

1. Fu, G., Zhao, D.H. Cheng, H.F. (2011). Comparison and analysis of comprehensive utilization of dredged materials. Port \& Waterway Engineering, 201(1): 90-96.

2. Zhang, X.D., Qi, J.Y. (2005). Resource utilization of dredging sediment. Northern environment, 30(2): 48-50.

3. Wilcock, D.N. (1999). River and inland water environments. Environmental Management in Practice, 3: 328 .

4. Olivares-Rieumont, S., de la Rosa, D., Lima, L., et al (2005). Assessment of heavy metal levels in Almendares River sediments-Havana City, Cuba. Water Research, 39: 3945-3953.

5. Chow, T.E., Gaines, K.F., Hodgson, M.E., Wilson, M.D. (2005). Habitat and exposure modeling for ecological risk assessment: a case study for the raccoon on the Savanah River Site. Ecological Modelling, 189: 151-167.

6. Hope, B.K. (2006). An examination of ecological risk assessment and management practices. Environment International, 32 (8): 983-995.

7. Mertens J., Vervaeke P., De Schrijver A., et al. (2004). Metal uptake by young trees from dredged brackish sediment: limitations and possibilities for phytoextraction and phytostabilisation. Science of the total Environment, 326(1): 209-215.

8. Xia, Z.H., Ge, W.Y. (1995). Research on sediment treatment of pollution in Shanghai. Water conservancy and hydropower technology, 4: 50-53.

9. Shao, L.M., He, P.J. (2003). Characteristics of urban polluted dredged materials and feasibility study of its beneficial use as greening vegetative soil. Shanghai environmental science, 12(22): 962-966.

10. Liu, W.G., Wu, Y. (2006). The Yangtze River has been suffering from "early cancer", pollution control in need. http://www.xinhuanet.com/chinanews/2006-03/01/co ntent_6349953.htm

11. Muller G. (1969). Index of geoaccumulation in sediments of the Rhine River. Geojournal, 2: 
108-118.

12. Loska K., Wiechula D. (2003). Application of principal component analysis for the estimation of source of heavy metal contamination in surface sediments from the Rybnik Reservoir. Chemosphere, 51: $723-733$. 